\title{
HEMOGLOBIN VALUES IN ADULT WOMEN OF VARIOUS OCCUPATIONAL GROUPS IN THE COMMUNITY
}

\author{
Makoto Futatsuka, * Yoshiki Arimatsu,* Tadako Ueda, ${ }^{* *}$ \\ Junichi Misumi, ${ }^{* * *}$ Hiroshi Maeda, ${ }^{*}$ Shigeru Nomura, ${ }^{*}$ \\ Atsushi UEDA** and Toshio MAtsushita** \\ 婦人労㗢者の血液水準に関する研究 \\ 二塚 信*, 有松 徳樹*, 上田 忠子**, 三角 順一***, 前田 寛* \\ 野村 茂*, 上田 厚**, 松下敏夫**
}

In 1966 and 1971, the authors studied hemoglobin values of about 2,000 women of 10 different occupational groups and different social classes in the same district. The mean values of hemoglobin and serum iron were highest in nursing students followed by urban housewives and nutritionists and lowest in 3 groups of farm wives and shoe factory laborers. The difference in the mean values of hemoglobin observed among occupational groups was in principle assumed to be due to the difference of frequency in levels of 11-12 g/dl. Hemoglobin levels between 1966 and 1971 tended to improve as a whole and the differences among occupational groups have been reduced. In this study, some kinds of social conditions as well as some physiological factors related to hemoglobin values were investigated. In the same occupational group, unmarried women had a higher level of hemoglobin than married women. Further, married women with infants showed a relatively lower level than those with no infants. This suggests that hemoglobin values of female workers may be significantly influenced not only by work conditions but also by social conditions including family circumstances.

\section{INTRODUCTION}

Adult women are said to have a tendency to develop anemia due to chronic loss of blood by menstruation and androgen-depressing effects on RBC productivity. ${ }^{1)}$ Detailed studies of female hemoglobin values have already been made both epidemiologically and hematologically. ${ }^{2-6}$ )

\footnotetext{
* Department of Public Health, Kumamoto University Medical School

** Department of Hygiene, Faculty of Medicine, Kagoshima University

*** Department of Hygiene, Kumamoto University Medical School

Received for publication, September 12, 1983

* 能本大学医学部公整衛生学教室

** 鹿競島大学医学部衛生学教室

**** 能本大学医学部衛生学教室 昭和58年 9 月 12 日受付
}

However, the women studied in many papers were limited to one district and a few social groups, or the data were processed without giving attention to socio-ecological characteristics.

Generally speaking, a higher frequency of anemia is thought to appear in farm wives who have problems both with nutritional intake and with labor conditions. $^{7-8)}$ However, it is still uncertain whether anemia is really higher in farm wives than in women of other occupations including housewives in urban areas. If there is a difference the causes have yet to be determined.

In 1966 and 1971, the authors studied the levels of hemoglobin and blood serum of women of different occupational groups and different social classes in a given district. The results have been reported in part. ${ }^{10)}$ 


\section{SUBJECTS AND METHODS}

In Kumamoto Prefecture, located southwestern Japan, female populations of the following 10 occupational groups were investigated in 1971: shoe factory workers $(n=69)$, tobacco factory workers $(n=338)$, transportation workers $(n=109)$ department store saleswomen $(n=69)$, nutritionists, ( $n=153$ ), nurses $(n=190)$, nursing students ( $n=$ 153), urban housewives (upper-middle class: Most of inhabitants were in administrative posts or skilled laborers in an old residental quarter) $(n=175)$, suburban housewives in a newly developed housing area (lower middle class: Most of inhabitants were so-called blue collar) $(n=85)$ and farm wives ( $n=697$ ). Table 1 indicates the respective ages within each group. The results from 6 of these 10 groups, i.e., shoe factory workers, nutritionists, nurses, nursing students, urban housewives and farm wives were compared with the results of a 1966 investigation carried out in the same season under similar conditions. This follow-up study disclosed changes in hemoglobin levels for various age and occupational groups.

By interview using a standardized questionnaire, family history including diet, pregnancy, parity and menstrual condition were recorded. ${ }^{8}$ ) The authors investigated intake of fish, meat, eggs, milk, oil and fat. The frequency of intake per week was divided into 4 classes and scored on the basis of 20 points. Table 2 shows the outline of labor conditions in those groups studied.

Hemoglobin was measured by the cyanmethemoglobin method, immediately after collection of blood from the cubital vein approximately 3 hours

Table 1. Number of subjects by age and occupational group.

\begin{tabular}{lccccccc}
\hline \multirow{2}{*}{ Occupational groups } & \multirow{2}{*}{ Numbers } & \multicolumn{6}{c}{ Age groups } \\
\cline { 3 - 7 } & & $10-19$ & $20-29$ & $30-39$ & $40-49$ & $50-59$ & Omission \\
\hline Shoe factory workers & $69(100)$ & $18(26.1)$ & $46(66.7)$ & $3(4.4)$ & $1(1.5)$ & 0 & $1(1.5)$ \\
Tobacco factory workers & $338(100)$ & $2(0.6)$ & $70(20.7)$ & $125(37.0)$ & $87(25.7)$ & $17(5.0)$ & $38(11.2)$ \\
Transportation workers & $109(100)$ & $20(18.4)$ & $57(52.3)$ & $9(8.3)$ & $5(4.6)$ & $2(1.8)$ & $16(14.7)$ \\
Department store sales- & $69(100)$ & $21(30.4)$ & $33(47.8)$ & $4(5.8)$ & $8(11.6)$ & $1(1.5)$ & $2(2.9)$ \\
$\quad$ women & & & & & & & \\
Nutritionists & $105(100)$ & 0 & $84(80.0)$ & $12(11.4)$ & $8(7.6)$ & $1(1.0)$ & 0 \\
Nurses & $190(100)$ & $4(2.1)$ & $97(51.1)$ & $31(16.3)$ & $27(14.2)$ & $5(2.6)$ & $26(13.7)$ \\
Nursing students & $153(100)$ & $78(51.0)$ & $66(43.1)$ & $1(0.7)$ & 0 & 0 & $8(5.2)$ \\
Urban housewives & $175(100)$ & 0 & $4(2.3)$ & $32(18.3)$ & $53(30.3)$ & $60(34.3)$ & $26(14.9)$ \\
Suburban housewives & $85(100)$ & 0 & $7(8.2)$ & $25(29.4)$ & $19(22.4)$ & $22(25.9)$ & $12(14.1)$ \\
Farm wives & $633(100)$ & 0 & $79(12.5)$ & $208(32.9)$ & $247(39.0)$ & $99(15.6)$ & 0 \\
\hline Total & $1,926(100)$ & $143(7.4)$ & $543(28.2)$ & $450(23.4)$ & $455(23.6)$ & $207(10.8)$ & $129(6.7)$ \\
\hline
\end{tabular}

Table 2. Labor conditions of occupational groups.

\begin{tabular}{ll}
\hline Shoe factory workers & $\begin{array}{l}\text { Shoemaking from crude rubber (not including laborers using organic } \\
\text { solvents), without nightshift, 8-hour day }\end{array}$ \\
\hline Tobacco factory workers & Cigarette making from leaf tobacco, without nightshift, 8-hour day \\
\hline Transportation workers & Mainly female conductors, without nightshift, 8-hour day \\
\hline Saleswomen & $\begin{array}{l}\text { Mainly saleswomen (shopgirls), standing all the time, without } \\
\text { nightshift, 8-hour day }\end{array}$ \\
\hline Nutritionists & $\begin{array}{l}\text { Managing food supplies in offices, hospitals and schools, without } \\
\text { nightshift, 8-hour day }\end{array}$ \\
\hline Nurses & $\begin{array}{l}\text { Caring for patients in large general hospitals, with nightshift, 8-hour } \\
\text { day }\end{array}$ \\
\hline Farm wives & Agricultural labor with their husbands, 9 12-hour day \\
\hline
\end{tabular}


after breakfast, namely, between 10 and 12 a.m. At the same time, the specific gravity of the blood and the packed cell volume were also measured. Furthermore, the blood carefully processed without contamination by iron, was brought back to the laboratory and the serum iron was measured according to the bathophenanthroline method. ${ }^{11)}$ The period of investigation was limited to the period from May to July in consideration of seasonal variations of blood values.3)
From the results obtained, mean values and frequency of anemia based on WHO standards were calculated by occupation, age. In addition, comparison between occupation and variation by year were examined by $t$-test and $\chi^{2}$-test.

\section{RESULTS}

Figure 1 shows the frequency distribution of hemoglobin for 4 occupational groups in 1971.

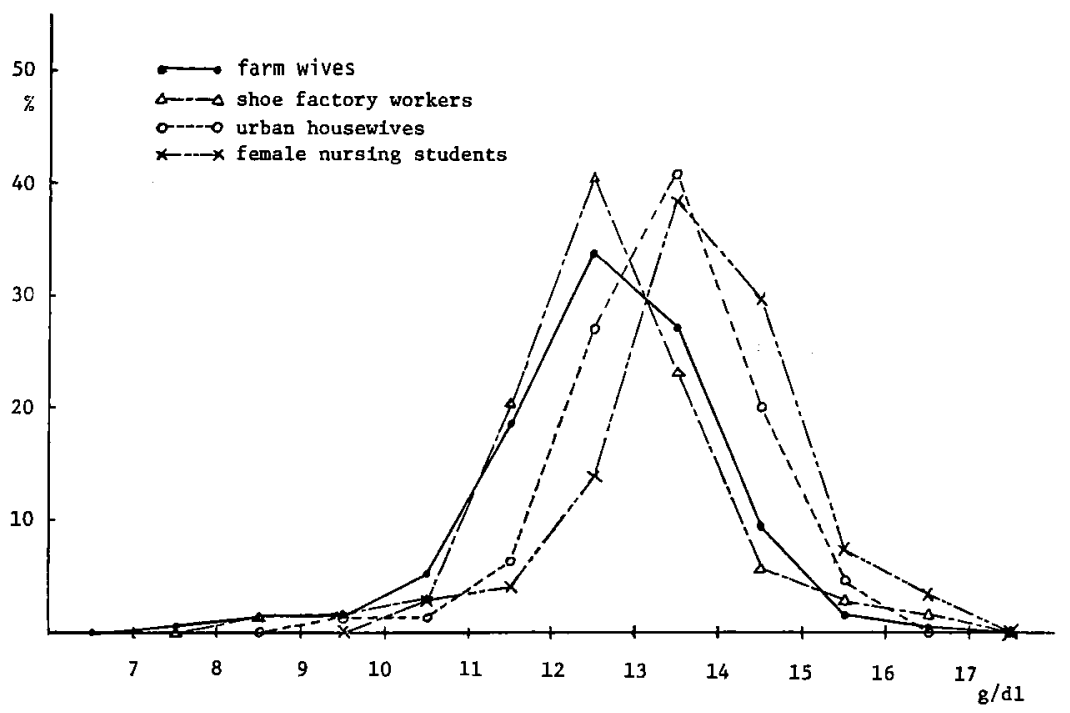

Fig. 1. Frequency distribution curves for hemoglobin values.

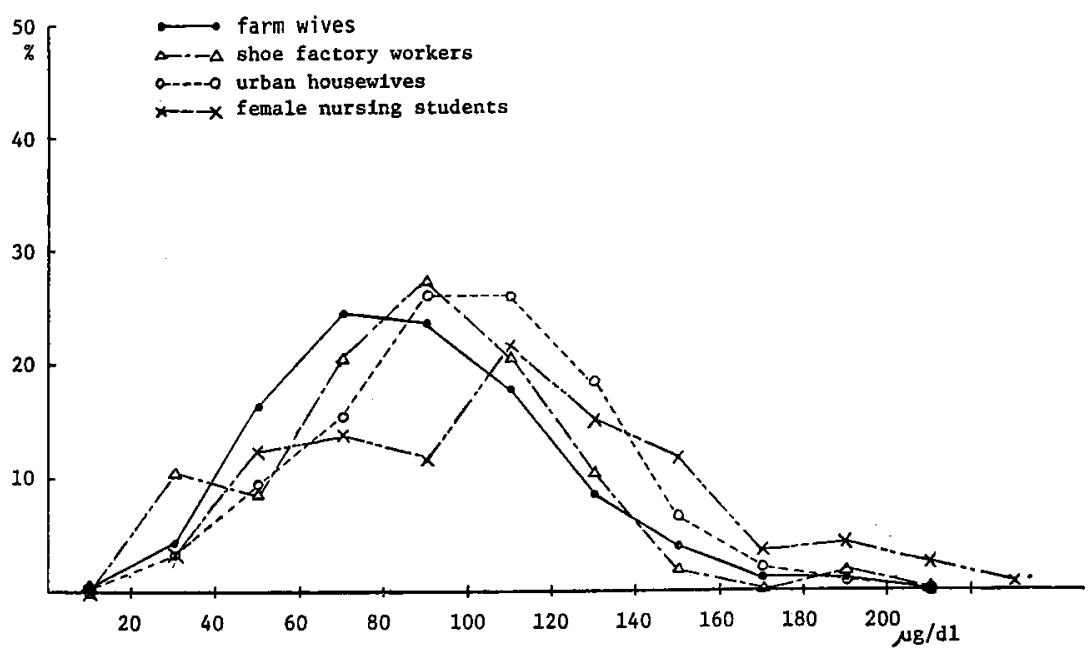

Fig. 2. Frequency distribution curves for serum iron values. 


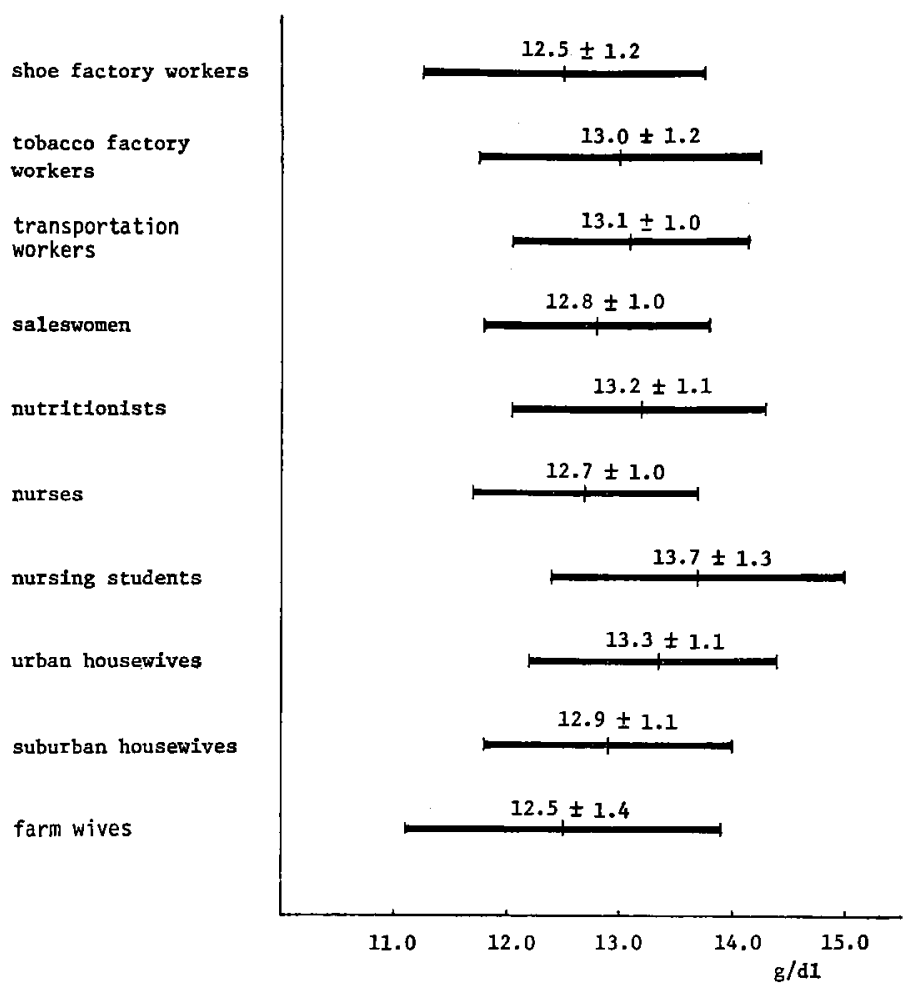

Fig. 3. Mean values of hemoglobin by occupational group (mean $\pm S D$ ).

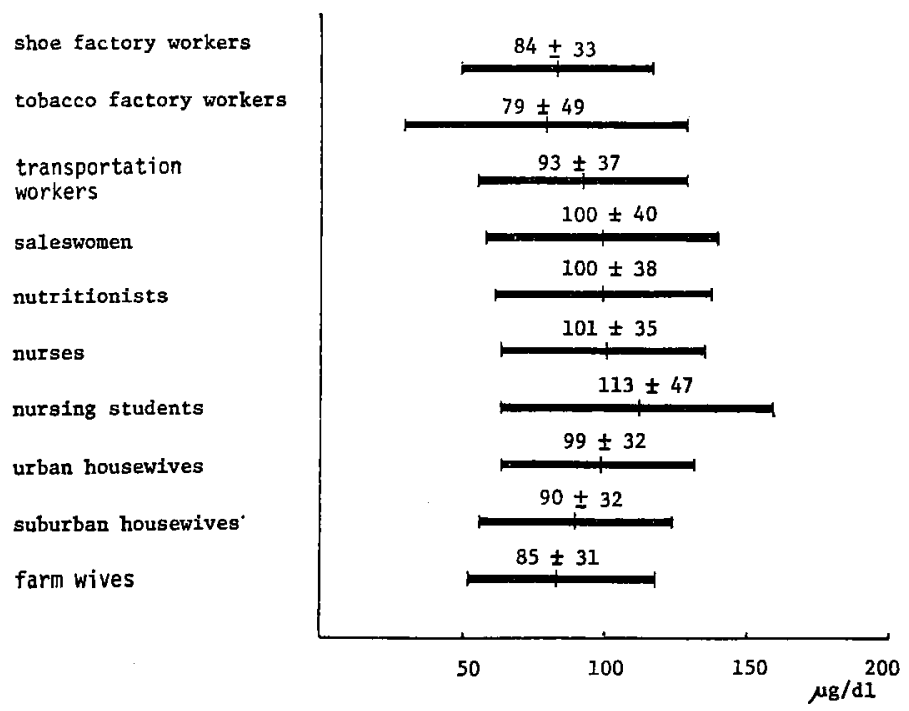

Fig. 4. Mean values of serum iron by occupational group (mean $\pm \mathrm{SD}$ ). 
Figure 2 shows the frequency distribution of serum iron. All groups showed a normal distribution with skewness in low values, while serum iron also showed a normal distribution skewed in the high range.

The mean values and standard deviation of hemoglobin and serum iron by occupational group are shown in Fig. 3. Hemoglobin was highest in nursing students with $13.7 \pm 1.0 \mathrm{~g} / \mathrm{dl}$ and lowest in farm wives with $12.5 \pm 1.4 \mathrm{~g} / \mathrm{dl}$ and in shoe factory workers with $12.5 \pm 1.2 \mathrm{~g} / \mathrm{dl}$, respectively. Furthermore, as shown in Fig. 4, serum iron did not necessarily vary in parallel with hemoglobin, being highest in nursing students of $113 \pm 47 \mu \mathrm{g} / \mathrm{dl}$ and lowest in tobacco factory workers with $79 \pm 49 \mu \mathrm{g} / \mathrm{dl}$.

As shown in Figs. 3 and 4, among the abovo

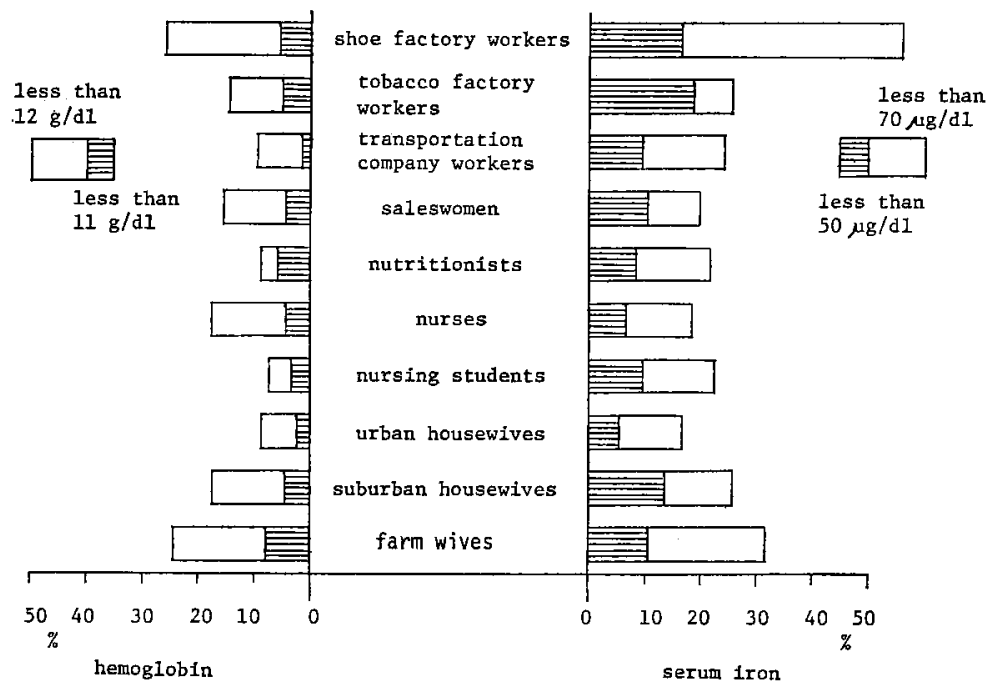

Fig. 5. Prevalence rate of persons with low hemoglobin values and low serum iron values.
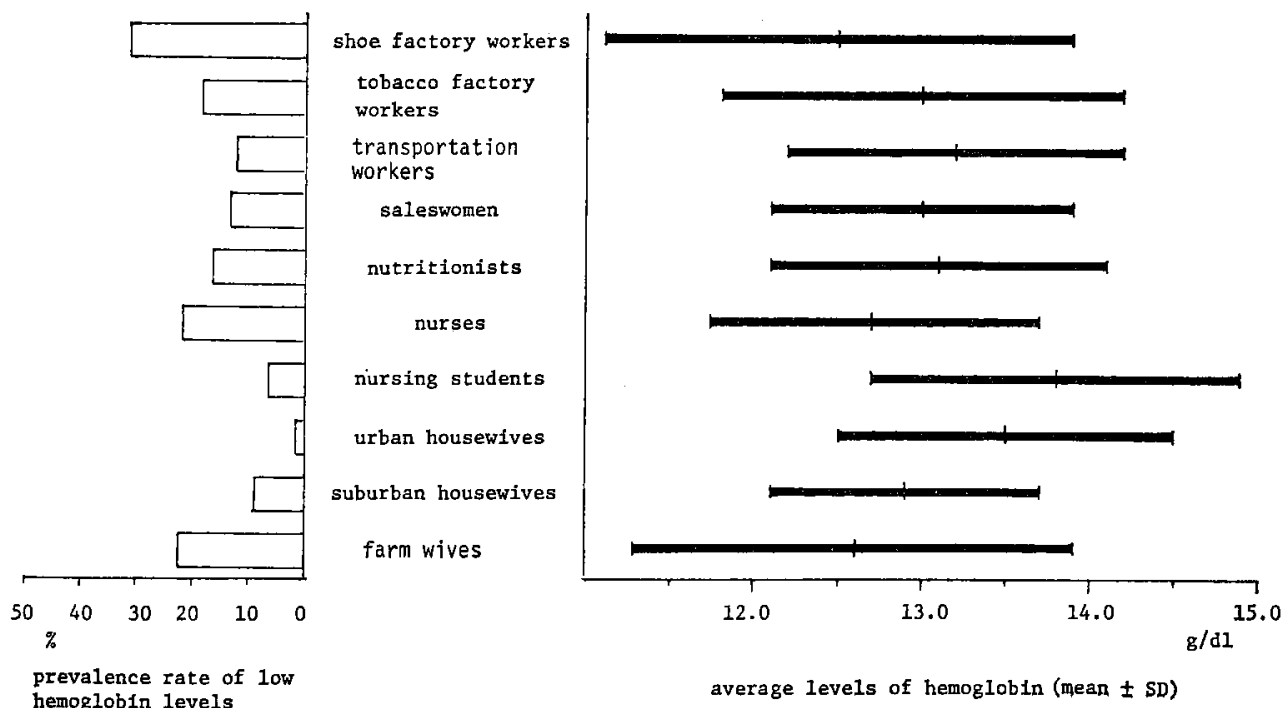

average levels of hemoglobin (mean \pm SD)

Fig. 6. Hemoglobin values by occupational group of subjects in their twenties. 
groups there were some differences, in particular in hemoglobin level. Nursing students had significantly higher values $(p<0.01)$ than any other group, while farm wives and shoe factory workers showed significantly lower values $(p<0.05)$ followed by nurses and saleswomen.

Figure 5 shows the prevalence rate of persons with low hemoglobin levels and low serum iron levels. The prevalence rate of anemia (less than $12 \mathrm{~g} / \mathrm{dl}$ ) was relatively high in farm wives and shoe factory workers, being $24.7 \%$ and $26.1 \%$ respectively. On the other hand, nursing students $(7.1 \%)$, urban housewives $(8.5 \%)$, nutritionists $(9.0 \%)$ and transportation company workers
(9.9\%) showed prevalence rates of less than $10 \%$. There was no apparent difference in the prevalence rate of persons with hemoglobin levels less than $11 \mathrm{~g} / \mathrm{dl}$. Thus the difference in the prevalence rate of anemia observed among occupational groups was in principle assumed to be due to the difference of frequency in levels between 11-12 $\mathrm{g} / \mathrm{dl}$. As shown in Fig. 5, the frequency of serum iron with less than $70 \mu \mathrm{g} / \mathrm{dl}$ was highest in shoe factory workers at $55.6 \%$, followed by the farm wives with $31.5 \%$. Urban housewives ( $16.3 \%$ ) had the lowest frequency. Frequency of less than $50 \mu \mathrm{g} / \mathrm{dl}$ serum iron was high in tobacco factory workers $(18.8 \%)$ and shoe factory workers $(16.7 \%)$, while
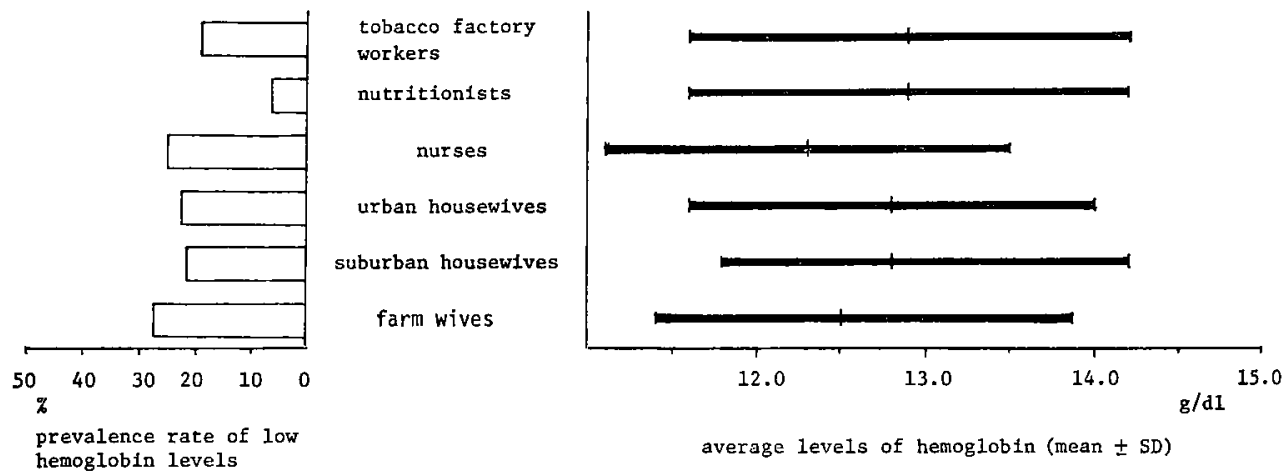

average levels of hemoglobin (mean $\pm S D$ )

Fig. 7. Hemoglobin values by occupational group of subjects in their thirties.

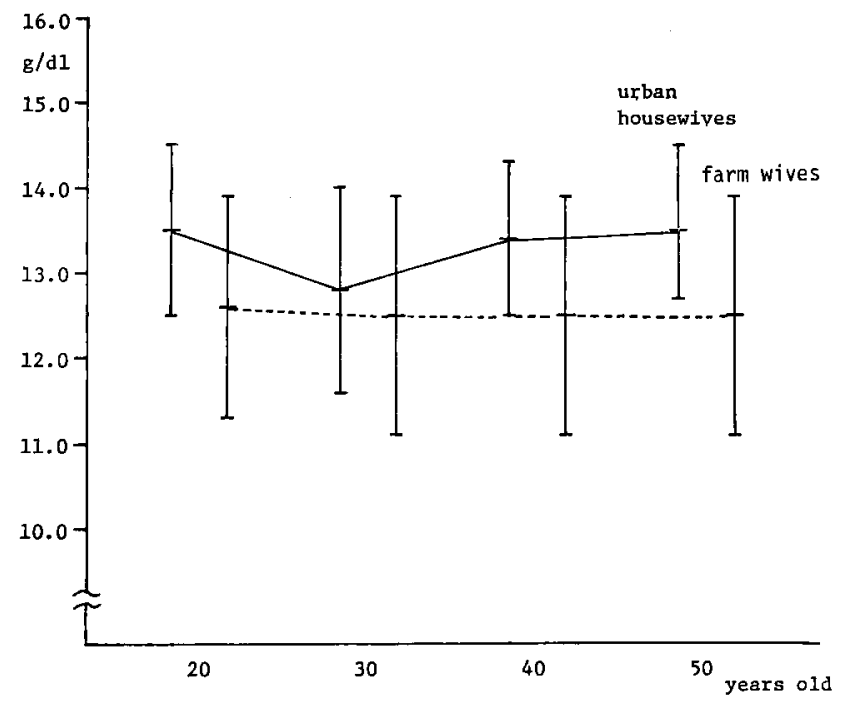

Fig. 8. Variation pattern of hemoglobin values by age in urban housewives and farm wives (mean $\pm S D$ ). 

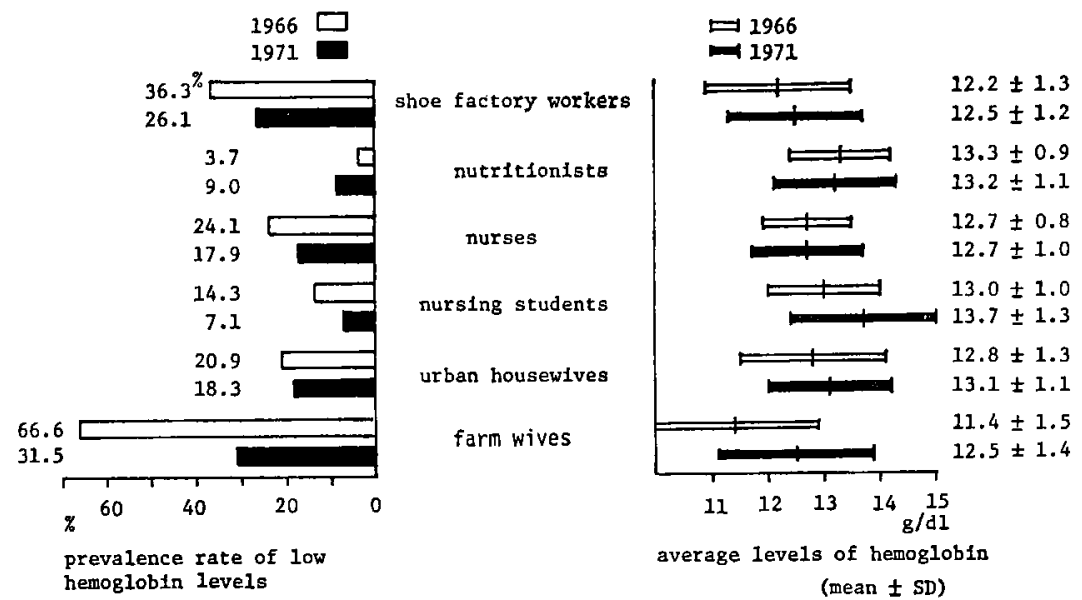

Fig. 9. Changes of hemoglobin values by occupational group between 1966 and 1971.

in urban housewives $(5.2 \%)$ and nurses $(6.3 \%)$ it was low. Frequency of those assumed to have iron deficiency anemia on measurement of hemoglobin and serum iron were distributed in the range from $12-13 \%$ among shoe factory workers and farm wives to $4-5 \%$ among nursing students, transportation workers, and urban housewives.

The above results suggest that those having latent iron deficiency were two or three times more numerous than those with iron deficiency anemia.

As stated above, the age composition differs by occupational group, so to adjust for age factors, groups of comparable age were selected for study.

Figure 6 shows the hemoglobin values by occupational groups in their twenties. There were relatively low levels in shoe factory workers $(12.5 \pm$ $1.4 \mathrm{~g} / \mathrm{dl})$, nurses $(12.7 \pm 1.0 \mathrm{~g} / \mathrm{dl})$ and farm wives $(12.6 \pm 1.3 \mathrm{~g} / \mathrm{dl})$, and higher levels in urban housewives $(13.5 \pm 1.0 \mathrm{~g} / \mathrm{dl})$, while the other groups were all in the range of $13.0-13.5 \mathrm{~g} / \mathrm{dl}$ of mean hemoglobin values.

The results for women in their thirties, as shown in Fig. 7, indicate a trend toward less difference in hemoglobin levels between occupational groups than those in any other age group. No group exceeded $13 \mathrm{~g} / \mathrm{dl}$ in mean value of hemoglobin: thus the prevalence rate of anemia as a whole tended to be lower than in other age groups. Among women in their thirties, $20-30 \%$ of all groups except nutritionists showed a frequency of less than $12 \mathrm{~g} / \mathrm{dl}$.

Figure 8 compares the hemoglobin level of urban housewives and farm wives in the twenty to fifty year-age range. There was no common pattern discernable between the urban housewives and the farm wives. A trend toward increased differences in levels between the urban and the rural areas in the fifties age group was worthy of notice.

Figure 9 shows the changes between 1966 and 1971 in these 6 occupational groups. The hemoglobin level tended to improve as a whole. For instance, the farm wives, who were in the lowest level in 1966, showed a marked improvement from $11.4 \pm 1.5 \mathrm{~g} / \mathrm{dl}$ to $12.5 \pm 1.4 \mathrm{~g} / \mathrm{dl}$ in mean values, and from $66.6 \%$ to $31.5 \%$ in the prevalence rate of anemia.

On the other hand, nutritionists, who in 1966 showed the highest mean hemoglobin level of $13.3 \pm 0.9 \mathrm{~g} / \mathrm{d} 1$ remained essentially unchanged.

\section{DISCUSSION}

Various factors are related to the differences of hemoglobin values. Hemoglobin values represent the dynamic equilibrium between synthesis and decomposition, basically reflecting the balance between intake of nutrition and energy consumption. Therefore, in groups with differenct environments a difference in hemoglobin values which corresponds with the characteristics of those groups may possibly be observed.

Around 1955 the hemoglobin values in various occupational groups among both males and females in Japan were clarified by 17 research institutions in a study headed by E. Komiya. ${ }^{12)}$ In 
males, the best results were observed in members of the Defense Force followed by students, office workers (clerks), factory workers, fishermen, and farmers in that order. In females, nearly the same trend was observed. Since then no other wide range systematic investigation except that of the Japan Industrial Hygiene Association Research Committee on male factory workers (1964) has been carried out. ${ }^{13)}$

As shown in Fig. 9, it can be said that in recent years the hemoglobin level is improving generally, while the difference in hemoglobin values between the occupational groups has been reduced.

The authors tried to compare by occupational group the hemoglobin values of females of nearly the same age and dwelling in the same district. The factors which influence hemoglobin values are considered to be: (1) physiological factors such as age, sex, season of the year, menstruation, pregnancy and parturition, (2) disease factors such as iron-deficiency anemia, megaloblastic anemia, hemolytic anemia and secondary anemia due to other diseases, (3) labor condition (occupation, position, size of enterprise, years of experience, intensity of work load, working hours, working system and working environment), (4) living conditions (income, diet, leisure and sleeping conditions). These various factors have a complex

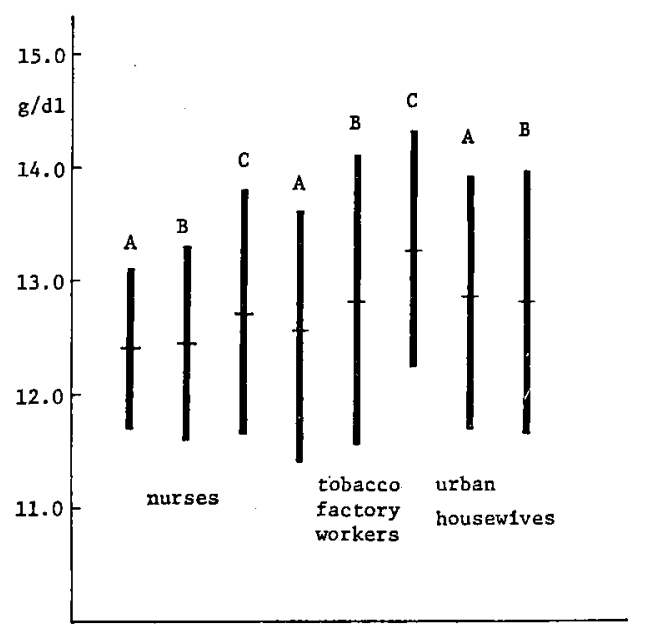

$$
\left.\begin{array}{l}
\text { A : with Infant } \\
\text { B : vithout Infant }
\end{array}\right\} \text { married }
$$

Fig. 10. Relationship between hemoglobin values and care of infants (mean $\pm \mathrm{SD}$ ). interrelationship affecting the hemoglobin values.

As stated above, the investigation took into consideration the age factor, and excluded seasonal variations by limiting the study to one season. By excluding those under medical care, and by selecting healthy adult females, it was attempted to eliminate clinical disease as a factor. Thus labor conditions and living conditions as well as some physiological factors were studied.

Figure 10 shows that unmarried female workers had a higher level of hemoglobin than married ones. Further, married working women with infants showed relatively lower levels than those with no infants. However, housewives showed no difference whether they had infants or not. These results indicate the work load is probably the modifying factor on hemoglobin values. Those in their twenties and thirties in some occupational groups were examined for a relationship between the number of pregnancies and the hemoglobin values, but no differences were observed.

In a study of ethnic differences in hemoglobin distribution of Asian and European Jewish women in Israel, both pregnant and nonpregnant, the age, parity, extent of supplementation during and after pregnancy, and the length of time since their last delivery were comparable in the two ethnic groups. ${ }^{14-15)}$ However, the Asians belonged to a lower social class than the Europeans. The lack of statistically significant ethnic differences in pregnancy anemia may have resulted from no difference in mean parity, in iron supplementation, or in the time which had passed since last delivery between Asians and Europeans, since high rates of anemia among Asian pregnant women were previously noticed when the above factors differed.

It is not necessarily easy to compare the work load between different types of work, thus differences of hemoglobin level for different work loads in the same occupation were studied in the group of nurses. Factors used in computing the influence of the work load on the hemoglobin level were as follows: married vs. unmarried, no night shift, up to 8 days $\cdot$ month $^{-1}$ night shift, and over 8 days night shift. Table 3 shows that married nurses with more than 8 days. month $^{-1}$ night shift had lower hemoglobin levels. It can be assumed that this is due to the fact that the night shift causes irregular meal times in addition to fatigue and insufficient sleep.

Nutritional condition plays a very important role 
Table 3. Relationship between levels of blood values and work conditions in nurses (mean $\pm \mathrm{SD}$ ).

\begin{tabular}{|c|c|c|c|c|c|}
\hline & & \multicolumn{2}{|c|}{$\begin{array}{l}\text { Specific gravity of } \\
\text { whole blood }\end{array}$} & \multicolumn{2}{|c|}{ Hemoglobin } \\
\hline & & Mean value & $\begin{array}{l}\text { Less than } \\
1.052\end{array}$ & Mean value & $\begin{array}{c}\text { Less than } \\
12.0\end{array}$ \\
\hline \multicolumn{6}{|c|}{ Unmarried } \\
\hline \multirow{3}{*}{ Nurses } & Without nightshift & $* 1.0534 \pm 0.0023$ & $11.8 \%$ & $12.96 \pm 0.92$ & $11.8 \%$ \\
\hline & $\left\{\begin{array}{l}\text { With nightshift up to } \\
8 \text { days/month }\end{array}\right.$ & $* * 1.0527 \pm 0.0025$ & $* * 30.4$ & $* * 12.74 \pm 0.98$ & 16.7 \\
\hline & Nightshift $>8$ days/month & $* * 1.0528 \pm 0.0024$ & $* * 25.7$ & $* * 12.69 \pm 1.11$ & 14.3 \\
\hline \multicolumn{2}{|c|}{ Nutritionists } & $1.0544 \pm 0.0020$ & 3.4 & $13.23 \pm 1.04$ & 11.8 \\
\hline \multicolumn{6}{|l|}{ Married } \\
\hline \multirow{3}{*}{ Nurses } & Without nightshift & $1.0525 \pm 0.0026$ & $* * 39.1$ & $12.65 \pm 0.98$ & 18.2 \\
\hline & $\left\{\begin{array}{l}\text { With nightshift up to } \\
8 \text { days/month }\end{array}\right.$ & $* * 1.0517 \pm 0.0015$ & $* * 45.0$ & $* 12.28 \pm 0.63$ & 25.0 \\
\hline & 'Nightshift $>8$ days/month & $* * 1.0515 \pm 0.0015$ & $* * 50.0$ & $* 12.28 \pm 0.57$ & 23.5 \\
\hline \multicolumn{2}{|c|}{ Nutritionists } & $1.0535 \pm 0.0023$ & 5.6 & $12.93 \pm 1.11$ & 11.7 \\
\hline
\end{tabular}

${ }^{*} p<0.05,{ }^{* *} p<0.01$, nurses $<$ nutritionists

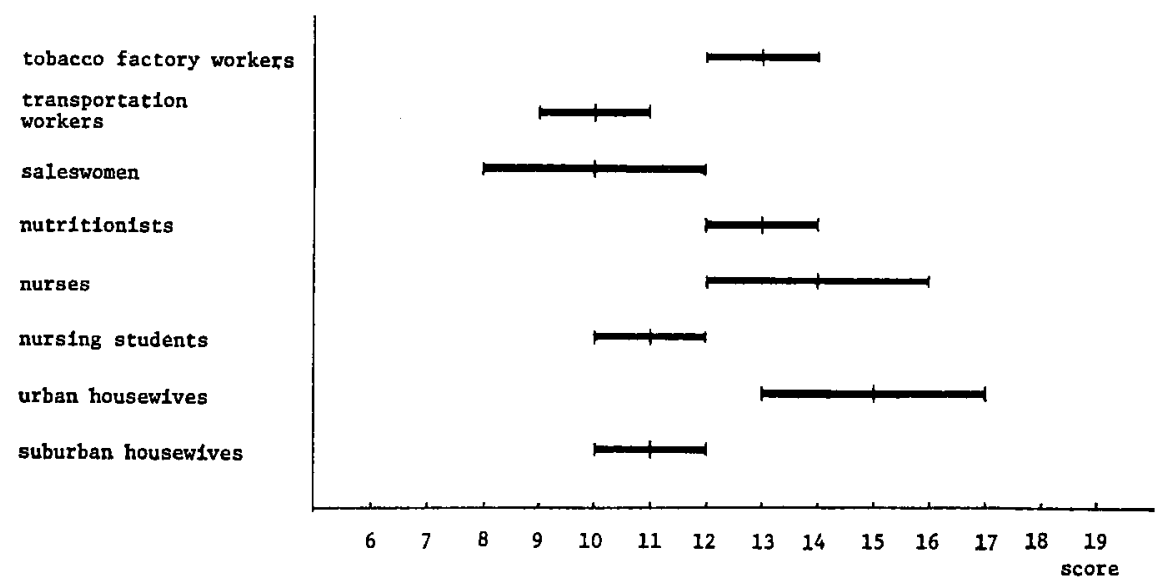

Fig. 11. Intake levels of animal protein and fat (mean \pm SD).

in regulating the hemoglobin values. ${ }^{16)}$ However, it is not always easy to investigate dietary conditions correctly and accurately. The results by occupational groups are shown in Fig. 11. The highest level was in nurses and urban housewives, and the lowest in the saleswomen and transportation company workers. As a whole, younger women and unmarried women had lower levels. The hemoglobin level did not necessarily correspond to diet. In the young and unmarried with comparatively light work, hemoglobin levels were higher in spite of slightly poorer nutrition. Between the urban and suburban housewives, it is interesting to note that while the work conditions correspond, nutrition seems to be the deciding factor in determining the hemoglobin level.

\section{REFERENCES}

1) WHO Technical Report Series: Nutritional anemias, Report of a WHO Scientific Group, No. 405, 1968.

2) Elwood, P.C.: Distribution of hemoglobin level, packed cell volume, and mean corpuscular haemoglobin concentration in women in the community, Br. J. Prev. Soc. Med., 18: 81-87, 1964.

3) Futatsuka, M., Arimatsu, Y., Ueda, A., Misumi, 
J., Tomio, T., Teruya, H., Ueda, T., Yasutake, R., Matsushita, $T$., Nomura, S.: The seasonal change of the blood properties of farmers, Jpn. J. Rural Med., 1: 32-45, 1973.

4) Hitoshi, T.: Studies on anemia in women in agricultural villages, J. Kurume Med. Soc., 33: 270-312, 1970.

5) Katzman, R., Novack, A., Pearson, H.: Nutritional anemia in an inner-city community relationship to age and ethnic group, J. Am. Public Health, 6: 670-673, 1972 .

6) Wintrobe, M.M.: Clinical Hematoloby, Lea \& Febiger, Philadelphia, 1974.

7) Expert Committee on Nutritional Anemia of Women in Rural Areas (Ministry of Health and Welfare, Japanese Government): An epidemiologic clinical studies on anemia in rural areas, J. Jpn. Assoc. Rural Med., 1: 56-58, 1977.

8) Matsushita, T.: Sociological etiology of anemia, in Living Condition and Anemia [Seikatsu to Hinketsu], 59-91, Ishiyaku Shuppan, Tokyo, 1972.

9) WHO Technical Report Series: Nutritional anemias, Report of a WHO Group of Experts, No. 503, 1972.

10) Futatsuka, M., Koyama, W., Arimatsu, Y., Ueda, A., Hitoshi, T., Ueda, T., Yasutake, R., Tanaka, S., Misumi, J. and Nomura, S.: Follow-up studies on the distribution of haemoglobin levels in female farm workers, J. Epidemiol. Community Health, 33: 286-291, 1979.

11) Matsubara, ; K.: The Iron and Hemoglobin [Tetsu to Hinketsu], Nankodo, Tokyo, 1963.

12) Komiya, E.: Normal Blood Values in Japanese [Nippon-jin no Seijo Ketsueki-zo], Nanzando, Tokyo, 1962.
13) Research Committee of Japan Association of Industrial Health: Physiological values of the blood of the Japanese industrial workers, Jpn. J. Ind. Health, 7: 3-45, 1964.

14) Palgi, A.: Ethnic differences in hemoglobin distribution of Asian and European Jewish women in Israel, both pregnant and nonpregnant, Am. J. Public Health, 71: 847-851, 1981.

15) Epstein, L.M., Bialik, O., Abramson, J.H. and Kark, S.L.: Changing hemoglobin picture among participants in Jerusalem, Isr. J. Med. Sci., 6: 267272,1970

\section{和 文 要 旨}

著者らは農村婦人の貧血について研究を進めている が，その一環として，1971年に一地方中核都市および周 辺農村に居住する10職種（製靴工場，専売公社，バス会 社, デパート従業員, 栄養士, 看護婦, 看護学生, 住宅 街および近郊団地主婦，農村婦人） 1,926 名を対象に血 色素, 血夜比重, へマトクリット, 血清鉄の測定を実施 した. その結果, 製靴工, 看護婦, 農村婦人が低值, 看 護学生，栄琸士，住宅街主婦が高値を示した。同じ年龄 層についてみても同様の傾向が見られた，製靴工，栄着 士, 看櫒婦, 看護学生, 住宅街主婦および農村婦人は 1966年にも同様の調查を実施しているが，農村婦人の血 色素水準の上昇が最も影著であった．同じ職種の中で は，未婚者より既婚者の血色素水準が低く，既婚者では 乳児を持つ母視の水集が低く, 婦人労働者の血色素水準 恃職場の労働条件のみならず, 家庭の条件に強く規定さ れていることが示㖫された。

Reprint requests to Department of Public Health, Kumamoto University Medical School, 2-1, Honjo 2-chome, Kumamoto, 860 Japan (M. Futatsuka) 著者への通信先 : 二塚 信, $\mathbf{\top} 860$ 能本 市本涯2-2-1 熊本大学医学部公䁬衛生学教室 